Şırnak Üniversitesi

Ilahiyat Fakültesi Dergisi

Sayı 26 Haziran 2021

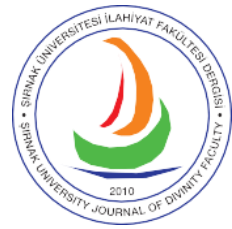

e-ISSN 2667-6575
Şırnak University

Journal of Divinity Faculty

Issue 26 June 2021

\title{
Temel Hedef ve Özellikleri Açısından Arap Edebiyatında Terim Sözlükleri
}

Glossaries in Arabic Literature in terms of Main Objectives and Features

\section{Selman YEŞİL}

Dr. Öğr. Üyesi, Siirt Üniversitesi, Yabancı Diller Yüksekokulu, Mütercim-Tercümanlık Ana Bilim Dalı Assistant Professor, Siirt University, School of Foreign Languages, Department of Translation and Interpreting

Siirt, Turkey

syesil4@hotmail.com

https://orcid.org/0000-0002-5885-0302

\section{Makale Bilgisi / Article Information}

Makale Türü / Article Types: Araştırma Makalesi / Research Article

Geliş Tarihi / Received: 25 Ocak / January 2021

Kabul Tarihi / Accepted: 22 Mart / March 2021

Yayın Tarihi / Published: 15 Haziran / June 2021

Sayı / Issue: 26 Sayfa / Pages: 339-363

Atıf / Cite as: Yeşil, Selman. "Temel Hedef ve Özellikleri Açısından Arap Edebiyatında Terim Sözlükleri [Glossaries in Arabic Literature in terms of Main Objectives and Features]". Şırnak Üniversitesi İlahiyat Fakültesi Dergisi - Şırnak University Journal of Divinity Faculty 26 (June 2021), 339363. https://doi.org/10.35415/sirnakifd.868084

Etik Beyanı / Ethics Declaration: Bu makalede bilimsel araştırma ve yayın etiği ilkelerine riayet edilmiştir. Makale etik izin gerektirmeyen bir çalışma olup en az iki hakem tarafından incelenmiş ve intihal içermediği teyit edilmiştir. / In this article, the principles of scientific research and publication ethics are respected. The article is a study that does not require ethical permission. It has been reviewed by at least two referees and was confirmed that it did not contain plagiarism. 


\section{Özet}

İslam dünyasında bilimsel dil birliğinin önemi erken dönemde anlaşılmış, Arapça kelimeleri sözlük anlamı açısından derleyen mu'cemler/sözlükler kaleme alındığı gibi bilimsel dil birliğinin sağlanması amacıyla terimleri konu edinen sözlük çalışmaları da yapılmıştır. Bu çalışmaların oluşum ve gelişimindeki temel etken ve hedef, İslam dininin kaynağ Kur'ân'ı koruma ve anlama çabasıdır. Bu amaçla sözlük çalışmalarının nüveleri sayılacak şekilde öncelikle nadir kullanılan kelimelerin anlaşılması için Kur'ân'da bulunan ve Garîbu'l-Kur'ân olarak isimlendirilen kelimeler derlenerek açıklanmıştır. İlerleyen süreçte bu çalışmalar muhteva açısından gelişerek Arapçadaki tüm kelimeleri kapsayacak hüviyete bürünmüştür. Bilindiği kadarıyla sözlük tanımına uyar şekildeki ilk örnek, 2/8. asırda Halîl b. Ahmed (öl. 175/791) tarafından verilmiştir. Ardından farklı yöntemlerle ama aynı amaca hizmet eden sözlük türleri ortaya çıkmıştır. İslami ilimlerde tedvin faaliyetlerinin olgunlaşması sonrasında fıkıh, hadis, tasavvuf ve kelam gibi bilim dallarında özgün terimler ortaya çıkmış ve bu anlamda zengin bir literatür oluşmuştur. Bu nedenle de söz konusu terimlerin hem kapsamlarının belirlenmesi hem de bilimsel anlamda dil birliğinin sağlanması amacıyla tek çatı altında derlenmesi ihtiyacı ortaya çıkmıştı. Çalışmamızda, İslam dünyasında bu amaçla kaleme alınan terim sözlüklerinin yakından tanınması ve bilimsel dil birliğine yönelik katkılarının ortaya konulması hedeflenmiştir. Bu hedef kapsamında öncelikle Arapça sözlüklerin tarihsel süreci, kaynakları, çeşitleri ve içerikleri hakkında kısa bilgi verilmiş, ardından da terim sözlükleri, kaynak, muhteva ve metot açısından incelenmiş ve gerek kendi içerisindeki etkileşimleri gerekse de diğer sözlüklerle olan etkileşimleri ortaya konulmuştur. Ayrıca söz konusu sözlükler metot açısından da kategorize edilmiş ve hedefledikleri amaca yönelik katkıları, eleştirel bir yaklaşımla tespit edilmeye çalışılmıştır. Terim sözlükleri "içerik" ve "dizayn" açılarından olmak üzere iki ana başlık altında incelenebilir. İçerik açısından terim sözlükleri de "Belli bir ilim dalındaki terimleri barındıran sözlükler" ile "İslami ilimlerdeki kavramları kapsayan sözlükler" şeklinde iki alt grupta incelenebilir. Birinci grup terim sözlükleri genelde belli bir bilim dalının terimlerini konu edinen sözlükler olup belli yazarların kendi mezhep terimlerini açıklamak üzere kaleme aldıkları eserlerdir. Ebû Hafs Necmüddîn Ömer b. Muhammed b. Ahmed en-Nesefî es-Semerkandî'nin (öl. 537/1142) Tilbetu't-talebe adlı eseri ile Kâsım elKonevî'nin (öl. 978/1571) fıkıh terimleri alanında yazdı̆̆ı Enîsü'l-fukahâ adlı eseri, bu türün tipik bir örneklerini oluşturmaktadır. İkinci grup ise tüm İslâmî bilim dallarına ait kavramları tek eserde toplayan eserlerdir. Bu tür sözlüklerin en tipik örneği Cürcânî'nin kaleme aldığı ve İslam dünyasında derin iz bırakan Kitâbu't-ta'rîfât adlı eserdir. Dizayn açısından ise kendi içerisinde farklı türleri bulunsa da genel olarak kavramların alfabetik dizilmesi tercih edilmiştir. Ancak Cürcânî'nin Ta'rîfât'ında yaptığ gibi kimi yazarlar ele aldıkları kavramın kullanım halini baz alıp alfabetik sıralamayı ilk harften başlatırken kimi yazarlar ise kavramın kök halini baz alarak yalın halindeki ilk harfin alfabetik sırasına göre kavramları sıralamıştır. Buna örnek olarak Muhammed Semir Necîb el-Lebîdî'nin $M u^{\prime} c e m u$ 'lmustalahâti'n-nahviyye ve's-sarfiyye adlı eserini vermek mümkündür.

Anahtar Kelimeler: Arap Dili ve Edebiyatı, Sözlükler, Terim Sözlükleri, Bilimsel Dil Birliği, Kavram. 


\section{Summary}

The importance of scientific language unity in the Islamic world was discerned in the early period, thus mu'cems / dictionaries that compiled Arabic words in terms of their lexical meanings were written while dictionary studies on the terms were also carried out to ensure scientific language unity. The main factor and goal in the formation and development of these studies is the effort to protect and understand the Quran, which is the source of Islam. For this purpose, the words in the Quran that are named Garîbu'l-Qur'an were compiled and explained to understand the rarely used words, in a way that counts as the core of the dictionary studies. In the following process, these studies have developed in terms of content and have claimed to cover all words in Arabic. As far as is known, the first example that complies with the dictionary definition was provided by Halil b. Ahmed (d. 175/791) in the $2 / 8^{\text {th }}$ century. Then, different types of dictionaries with distinctive methods yet serving the same purpose emerged. After the maturation of compilation activities in Islamic studies, some original terms emerged in the disciplines such as figh, hadith, mysticism, and kalam, and a body of enriched literature was formed. For this reason, it became necessary to compile the terms in question under a single roof to determine their scope and to ensure scientific language unity. This study aims to examine closely the glossaries written for this purpose in the Islamic world and to reveal their contributions to scientific language unity. Within this scope, primarily some brief information was provided about the historical process, sources, types, and contents of Arabic dictionaries, and then glossaries were examined in terms of source, content, and method, including their interactions both among themselves and with other dictionaries. Furthermore, the glossaries in question were categorized in terms of method, and their contribution to the objectives was determined with a critical approach. Glossaries can be examined under two main headings in terms of their "content" and "design". Regarding content, glossaries are divided into two subgroups: "dictionaries containing terms in a certain field of science" and "dictionaries covering the concepts in Islamic disciplines". The first group includes dictionaries dealing with the terms of a certain discipline and those written by certain authors to explain the terms relating to their sects. Abu Hafs Necmüddîn Ömer b. Mohammed b. Ahmed en-Nasafi as-Semerkandî's (d. 537/1142) Tilbetu't-talebe and Kasim al-Konevî's (d. 978/1571) Enîsü'l-fukahâ, written in the field of figh terms, are typical examples of this genre. The second group contains the works that gather the concepts of all Islamic disciplines in a single work. The most typical example of such glossaries is Cürcânî's Kitâbu'd-ta'rîfât, a work that left a profound influence in the Islamic world. In terms of design, although there are different types, it is generally preferred to arrange the concepts alphabetically. However, as Cürcânî applied in Ta'rîfât, some authors started the alphabetical order from the first letter, based on the usage of the concept they dealt with, while others listed the concepts according to the alphabetical order of the first letter in their nominative form, based on the root form of the concept. It is possible to give Mu'cemu'l-mustalahâti'n-nahviyye ve's-sarfiyye by Muhammed Semir Najib el-Lebîdî as an example to the second group.

Keywords: Arabic Language and Literature, Dictionaries, Glossaries, Scientific Language Unity, Concept. 


\section{Giriş}

Dünyadaki birçok bilimsel keşif ve icat, kolektif çabanın ve dayanışmanın ürünüdür. Bu çaba ve dayanışmanın daha etkin ve doğru sonuçlar doğurması için sağlıklı iletişim zorunludur. Halk arasında sağlıklı bir iletişim için nasıl ki kullanılan kelimelerin tüm bireyler tarafından aynı anlamı ifade etmesi gerekiyorsa bilimsel verilerin de sağlıklı şekilde aktarımı için bilimsel dil birliğinin sağlanması önemlidir. Bu nedenle de İslam dünyasında sözlük çalışmaları ortaya çıkmış; ilk olarak kelimeler halk dilindeki kullanımları baz alınarak derlenmiştir. Bunun neticesinde sözcük temelli sözlükler ortaya çıkmıştır. Bu tür sözlüklerin oluşum süreci hicrî birinci asrın ortalarına dayanmaktadır. Kur'ân' daki garîb kelimeler, atlar, otlar ve kuşlar gibi ortak paydaya sahip kelimelerle ilgili olmak üzere bir araya getirilen kelimelerin varaklara yazılması şeklinde başlayan sözlük çalışmaları, ${ }^{1}$ zamanla sistematikleşmiş ve bilindiği kadarıyla sözlük tanımına uyar şekildeki ilk örnek 2/8. asırda Halîl b. Ahmed (öl. 175/791) tarafından verilmiştir. Ardından farklı yöntemlerle ama aynı amaca hizmet eden sözlük türleri ortaya çıkmıştır.

İslam dünyasında sözlük çalışmaları ilerleyen süreçle beraber yöntem olarak farklılık gösterdiği gibi tür, amaç ve içerik olarak da bir farklılık göstermiştir. ${ }^{2} \mathrm{Bu}$ farklılığın en belirgin örneği olarak alan temelli veya kavram eksenli olan terim/1stılah sözlüklerinin ortaya çıkışı gösterilebilir. Bu tür sözlüklerde kelimelerin halk arasındaki kullanımından ziyade belli bir bilim dalına ait olan kavramlar ele alınmış ve detaylı bir şekilde incelenmiştir. Bu sözlükler hedef olarak kelime bazlı sözlüklerden farklı olsa da genel anlamda biçim ve yöntem olarak bu türün takipçisi olmuştur.

\section{Arap Edebiyatında Sözlük Çalışmalarının Tarihsel Süreci}

Arap edebiyatı literatüründe mu'cem/kâmûs/lugat isimleriyle bilinen sözlük çalışmaları, bireyler arasındaki iletişimin sağlıklı bir zemine oturtulmasını amaçladığı gibi dilin sonraki nesillere aktarımına da yönelik bir çabadır. Teknik anlamda bakıldığında sözlük kavramı şu şekilde tanımlanmıştır:

Bir dildeki sözcüksel birimlerin tümünü ya da bir bölümünü genellikle abecesel düzen, kimi durumlarda da konulara ya da kavramsal alanlara göre tanımları,

1 Ahmed Abdülğafûr Attâr, Mukaddimetü's-sihâh (Misır: 1956), 51; Hasan Zaza, Kelâmu'l-'Arab min kadâya'lluğati'l-'Arabiyye, (Beyrut: y.y., 1990), 160.

2 Sözlük çalışmalarının geçirdiği evreler hakkında geniş bilgi için bk., Ahmed Emin, Duha'l-İslam (Kahire: 1964), 2/263-270. 
tanıkları, söylenişleri, kökenleri, kullanımları, dilbilgisi ulamları, eşanlıları vb. ya da başka dildeki karşılıkları ile sunan yapıttır. ${ }^{3}$

Bir başka tanımda da sözlük kavramının farklı işlevine dikkat çekilerek şöyle tanımlanmıştır:

Herhangi bir dilde belirli bir mantık düzeniyle kelimeleri toplayan, her kelimenin anlamıyla bağlantı kurmayı hedefleyen ve kelimenin anlamına dair delil sunan veya nesne-kelime ilişkisini açıklayan kelimeler yığınına sözlük/mu'cem denir. ${ }^{4}$

Araplarda Kur'ân'ın nüzulü ile ilmî çalışmalar başlamış ve kısa zamanda sistematik hale gelerek özellikle İslamî ilimlerde hızlı bir ilerleme sağlamıştır. Bu ilimlerin ana kaynağı olan Kur'ân'ın ve hadislerin Arapça metin olması ve farklı sonuçlara götürebilecek şekilde yorumlanmaya elverişli ifadeler kapsaması, Arap diline yönelik sistematik çalışmaları da zorunlu hale getirmiştir. Öncelikle kelimelerin anlaşılması amacıyla Kur'ân ile hadislerde bulunan ve Garîbu'l-Kur'ân/Garîbu'l-hadis olarak isimlendirilen nadir kelimeler derlenerek açıklanmış, ${ }^{5}$ ardından bazı dilciler tarafından bitki, at, deve vb. nesnelere ait sözcükler herhangi bir sistem takip edilmeksizin bir araya toplanarak kitapçıklar oluşturulmuştur. ${ }^{6}$

İlerleyen süreçte Arapçanın korunması amacıyla dil kuralları tespit edilmiş ve sistematik bir düzene oturtulmuştur. Ardından da Kur'ân'da geçip geçmemesine bakılmaksızın Arapçadaki bütün kelimeler ile bu kelimelerin türevleri ve kullanım şekilleri derlenmeye başlanmıştır. İlk nüveleri at, deve, çöl gibi belirli ve ilintili kelimelerin derlenmesi veya kişisel notların yazılmasıyla ortaya çıkan sözlük çalışmalarının bilinen ve sözlük tanımına uyan ilk örneği, Halîl b. Ahmed tarafından kaleme alınan Kitâbu'l-'ayn adlı eserdir. ${ }^{7}$

Eserde, Arapçada kullanılan çok sayıda kelime, kendi içerisinde bir sistematiğe dayalı olarak derlenmiştir. İlk olması hasebiyle gerek kullanılan yöntem gerekse de derlenen kelimelerin yanı sıra verilen örnekler ve açıklamalar, diğer sözlük yazarları için yol gösterici

3 Berke Vardar, Açıklamalı Dilbilim Terimleri Sözlüğ̈̈̈ (İstanbul: 1998), 191.

4 Afif Abdurrahman, Min kadâye'l-mu'cemâti'l-'Arabiyyeti'l-mu'âstra (Tunus: Daru'l-Garbi'l-İslamî, 1986), 373; Farklı tanımlar için bk. Nassâr Hüseyin, el-Mu'cemu'l-Arabî, Neş'etuhu ve Tatavvuruhu (Mısır: 1988), 1/9; Doğan Aksan, Her Yönüyle Dil (Ankara: TDK Yayınları, 1995), 393.

5 Bu tür risalelerin ilki Abdullah b. Abbâs'a nispet edilmektedir. Imîl Bedî Yakub, el-Me'âcimu'l-lugaviyyetü'lArabiyye, (Beyrut: Dâru'l-ilm li'l-melâyîn, 1985), 26. Söz konusu risaleler hakkında bilgi için bk. Mehmet Yavuz, "Mu'arreb Kelimelere Dair Yazılan Eserler Sözlükler”, Nüsha (Şarkiyat Araştırmaları) Dergisi 1/2 (2001), 112-119; İbn Abbâs ve risalesi hakkında geniş bilgi için bk. Sezgin Fuat, GAS (Geschichte des Arabischen Schrittums), 9 cilt, (Leiden: 1967-1984), 1/25-28.

6 Attâr, Mukaddimetü's-sihâh, 50-51.

7 Tevfik Rüştü Topuzoğlu, "Halîl b. Ahmed”, Türkiye Diyanet Vakfı İslam Ansiklopedisi, (İstanbul: TDV Yayınları, 1997), 15/309-312. 
olmakla beraber taklit de edilmiştir. Ancak zamanla farklı sistematiğe ve içeriğe sahip sözlükler de kaleme alınmıştır.

Ahmed Emîn, Arap edebiyatındaki sözlük faaliyetlerinin evrelerini özet olarak üç aşamada değerlendirmektedir: İlk aşamada kelimeler herhangi bir ilişki gözetilmeksizin rastgele seçilmiştir. İkinci aşamada aynı paydaya sahip kelime grupları arasından seçilen kelimeler belli konu başlıkları altında dizilmiştir. Son olarak üçüncü aşamada ise Arapçanın hemen hemen bütün kelimelerini belli sistem dâhilinde kapsayan ve herhangi bir kelimenin anlamını araştıran okuyucuya kaynak olabilecek biçimde düzenli eserlerin ortaya çıktığı aşamadır. $^{8}$

Sözlük çalışmalarındaki temel amaçları ise şöyle izah etmek mümkündür: Kur'ân'1 yanlış okumaktan ve anlamaktan korumak, Arapçayı yabancı kelimelerin etkisinden muhafaza etmek, son olarak da Arapça kelimelerin zamanla kaybolmasını önlemek. ${ }^{9}$

\section{Arap Edebiyatında Sözlük Türleri}

Sözlüklerin temel amacl, dili korumak ve sonraki nesillere aktarmaktır. Zaman içerisinde dizayn ve sunum açısından farklılaşan sözlükler, amaç ve hedef açısından da farklılaşmıştır. Dizim açısından bakıldığında kelimelerin alfabetik olarak bir sisteme göre dizildiği örneklerin yanı sıra harflerin mahreci baz alınarak tasarlanan örneklerin de bulunduğu görülür. Derlenen kelimelerin alfabetik veya mahreç esasına dayalı olarak düzenlendiği sözlük türleri de kendi içerisinde farkl1lık gösterebilmektedir. Kitâbu'l-'ayn, örneğinde olduğu gibi kimi sözlüklerde kelimelerin kök halinin son harfinin mahreci dikkate alınmış ve sonrasında aynı kökten türeyen farklı kelimeler sıralanmıştır. Esâsü'l-belâga gibi kimi sözlüklerde de kelimenin yalın halinin ilk harfinin alfabetik sıralaması dikkate alınmıştır.

İslam dünyasında sözlüklerin biçim ve dizayn olarak değiştiği gibi amaç ve içerik olarak da değiştiği görülür. Telif amacı dili korumaktan ziyade belli bir bilim dalındaki terimlerin tanımını yapmak, alandaki konumunu tespit etmek ve bilimsel dilde birliği sağlamak olan terim sözlükleri bu farklılığın görüldüğü en belirgin türdür. Terim sözlükleri, kelimeleri sözlük anlamı açısından ele alan sözlükler gibi dizayn açısından farklılık göstermektedir. İleriki aşamada örnekleri görülecektir.

\footnotetext{
8 Ahmed Emin, Duha'l-İslam, (Kahire: y.y., 1964), 2/263-265.

9 Hüseyin Küçükkalay, Kur'ân Dili Arapça, (Konya: y.y., 1969), 61.
} 


\subsection{Kelime Bazlı Sözlükler}

Başta da belirtildiği üzere sözlük çalışmalarının temeli, kelimeleri toplumdaki anlamı açısından ele alan sözcük temelli sözlüklerdir. Bu sözlük türünün önde gelen ve sözlük tanımına uyan elimizdeki ilk eser, Halîl b. Ahmed'in "Kitâbu'l-'ayn" adlı eseridir. ${ }^{10}$ Eserin dizaynı, kelimelerin kök harflerinin mahreci esas alınarak düzenlenmiş ve kelimeler kendi içerisinde kalb usulü olarak adlandırılan bir sistematiğe göre dizilmiştir. Ancak bu sistemin, kullanımının zor olması nedeniyle sonraki süreçte devam etmediğini de belirtmek gerekir. Halîl b. Ahmed'in "Kitâbu'l-'ayn" eserinden sonra kaleme alınan sözlüklerin içeriğinde olduğu gibi dizim ve sistematiklerinde de çeşitlilik ortaya çıkmıştır. Ebû ‘Ubeyde el-Kâsım b. Sellâm (öl. 224/838) Arap edebiyatında kelimeleri elbiseler, yiyecekler, içecekler vb. konularına göre derleyen ve kitapçıklar halinde düzenleyen son derece farklı ve özgün bir sistemi, el-Garîbu'l-Musannef adlı eserinde kullanmıştır. ${ }^{11}$ Ancak bu sistem de kullanımındaki zorluk nedeniyle takipçi bulamamıştır.

Bazı müellifler de kelimelerin farklı bir boyutunu göz önüne alarak eserlerini sadece belli gruptan kelimelerle sınırlandırmışlardır. Bunlara örnek olarak el-Cevâlikî́nin yabancı kökenli olup Arapçaya sonradan geçen ve "Mu'arreb" olarak nitelendirilen kelimeleri barındıran el-Mu'arreb adlı eserinin yanı sıra Ebû Tayyib el-Lugavî'nin sadece (ezdâd) zıt anlamda kullanılabilen kelimeleri ihtiva eden el-Ezdâd adlı eseri ve el-Meydânî'nin (öl. 518/1124) Arap edebiyatındaki darb-1 meselleri derlediği Mecméu'l-emsâl adlı eseri gibi sözlükleri vermek mümkündür. Arap edebiyatında ortaya çıan kelime bazlı sözlükleri dizim açısından örnekleriyle şöyle gruplandırılabilir:

\subsubsection{Harflerin Mahreci Esas Alınarak Düzenlenen Sözlükler}

Bu türün en yaygın örneği Halîl b. Ahmed'in Kitâbu'l-'ayn adlı eseridir. Bu kategoride yer alan sözlüklerde kelimeler önce gırtlaktan çıkış sırasına göre, ardından dil, diş ve dudaktan çıkan harfler ve ardından da illetli harfler şeklinde tanzim edilmiştir. Ancak bu sistem kısa zaman sonra terk edilmiş, İbn Fâris'ten (öl. 395/1004) sonra gelen dilcilerden takipçi bulamamıştır. ${ }^{12}$ Kitâbu'l-'ayn dışında bu türe örnek olarak İbn Düreyd'in (öl. 321/933)

\footnotetext{
10 Tevfik Rüştü Topuzoğlu, "Halîl b. Ahmed”, Türkiye Diyanet Vakfı İslam Ansiklopedisi (İstanbul: TDV Yayınları, 1997), 15/309-312.

11 Imîl Bedî Yakub, el-Méâcimu'l-lugaviyyetü'l-Arabiyye, 100.

12 Imîl Bedî Yakub, el-Me'âcimu'l-lugaviyyetü'l-Arabiyye, 85-99.
} 
el-Cemhere adlı eseri ile Ebû Ali İsmâil b. Kâsım el-Kâlî (öl. 356/966) tarafından kaleme alınan el-Bâri' fî garîbi'l-luğati'l-Arabiyye adlı eser gösterilebilir.

\subsubsection{Alfabetik Sıra Esas Alınarak Düzenlenen Sözlükler}

$\mathrm{Bu}$ tür sözlükler, kelimenin ilk harfi veya sonra harfi baz alınarak alfabetik sıralamaya dayalı düzenlenen sözlük türüdür. Bu tür sözlükler kullanımı kolay olduğundan daha yaygın olmuştur. Özellikle son dönemlerde sözlüklerin hemen hemen hepsi bu şekilde dizayn edilerek kaleme alınır. Bu tür sözlükler de kelimenin kökeninin son harfini veya ilk harfini baz alanlar ile kelimeyi köken harfinden ziyade kullanıldığı şekildeki ilk harfi baz alarak sıralayanlar olmak üzere kendi içerisinde gruplara ayrılır. ${ }^{13}$ Ebû İbrâhîm İshâk b. İbrâhîm el-Fârâbî'nin (öl. 350/961) Dîvânu'l-edeb fî beyâni luğati'l-'Arab, İsmail b. Ahmed elCevherî'nin (öl. 393/1001) Tâcu'l-luğa ve sıhâhu'l-'Arabiyye ile Zemahşerî’nin (öl. 538/1144) Esâsü'l-belâga isimli eserlerini bu türe örnek olarak göstermek mümkündür.

\subsection{Terim Sözlükleri}

Kavram bazlı sözlükler biçim ve içerik açısından sözcük bazlı sözlükler gibi kendi içerisinde farklılık arz eder. Ancak kavram sözlüklerindeki farklılık başta örnekleri verilen kelime bazlı sözlüklerin biçim ve içerik farklılığından ayrı bir yapıdadır. Zira alan sözlükleri biçim olarak bazen telif edildikleri bilim dalının konu dizimine uygun şekilde sıralanırken bazen de alfabetik sıralamaya tabi tutulurlar. İçerik olarak da terim sözlüklerinin bir kısmı Kâsım el-Konevî́nin (öl. 978/1571) fıkıh terimleri alanında yazdı̆̆ı Enîsü'l-fukahâ adlı eserinde olduğu gibi belli alandaki bazı kavramları kapsarken, Seyyid Şerif Cürcânî'nin etTa'rîfât adlı eserinde görüldüğü üzere bazılarında ise kapsam geniş tutularak dönemin ilim dünyasında yaygın olarak kullanılan ilimlerdeki kavramların tümü ele alınmıştır.

Genel anlamda bakıldığında tüm sözlük çalışmalarının kökeninin Kur'ân eksenli çalışmalara dayandığını görmek mümkündür. Ancak kelime ve terim bazlı sözlükler arasında bir sıralama yapacak olursak kelime bazlı sözlüklerin terim bazlı sözlüklerden önce

13 Bu türler hakkında detaylı bilgi için şu eserlerde bilgi bulmak mümkündür: Cemal Muhtar, “İslâm’da Sözlük Çalışmaları II", Marmara Üniversitesi İlahiyat Fakültesi Dergisi 3 (1985), 353-354; M. Sadi Çöğenli - Kenan Demirayak, Arap Edebiyatında Kaynaklar (Erzurum: Fen-Edebiyat Fakültesi Yayınları, 1994), 122- 134; Suat Çelikkol, Sözlük Çalışmalarında Dilbilimsel Açıdan Yaklaşım ve Dr. Abdulvahid Kerem, 'Mucemu'l-Mustalahati'lKânuniyye' Adlı Eseri ve Türkçeye Tercümesi (Sivas: Cumhuriyet Üniversitesi, Sosyal Bilimler Enstitüsü, Yüksek Lisans Tezi, 1998), 22-35; Mehmet Nuri Alpak, Arap Dilinde Sözlük Çalışmaları ve Nazım Efendi'nin 'Tercümanu'llügat' Adlı Eserinin İncelenmesi (Van: Yüzüncü Yıl Üniversitesi, Sosyal Bilimler Enstitüsü, Yüksek Lisans Tezi, 2006). 
ortaya çıktığını ve terim sözlüklerinin hem sistem hem de biçim olarak bunlardan etkilendiğini söylemek yanlış olmayacaktır. Bu türün ilk örneğinin Ebû Ubeyd'in (öl. 224/838) "el-Garîbu'l-Musannaf" isimli çalışması olduğu kabul edilir. ${ }^{14}$

Terim sözlüklerinin ortaya çıkışındaki temel nedenler içerisinde ise kavramların mezhepsel açıdan tanımlanması ${ }^{15}$ ve herhangi bir bilim dalı kavramlarının ilgililere toplu bir şekilde sunulması gibi farklı nedenlerinin bulunduğunu söylemek mümkündür. Ancak en önemli hususun bilimsel dil birliğinin sağlanması olduğu söylenebilir. Çalışmamızın ana mihverini oluşturan kavram sözlükleri hem biçim hem de içerik olarak detaylıca işlenecektir.

\subsection{1. İçerik Açısından Terim Sözlükleri}

Terim sözlükleri içerik açısından incelendiğinde kelime bazlı sözlüklerden etkilenmelerine rağmen önemli bazı farklılıklara sahip oldukları görülür. Söz konusu bu türün, içerik açısından iki ana grupta incelenmesi mümkündür:

\subsubsection{Belli Bir İlim Dalındaki Terimleri Barındıran Terim Sözlükleri}

Bu tür sözlükler genelde belli bir bilim dalının terimlerini konu edinen sözlükler olup belli yazarların kendi mezhep terimlerini açıklamak üzere kaleme aldıkları eserlerdir. Ait oldukları ekolün mensupları tarafından kaleme alınmış olmaları ve içerik olarak kendi ekollerinin ana kaynaklarından beslenmeleri, söz konusu ekolün tanınması, anlaşılması ve temsil edilmesi açısından çok değerlidirler. Bu sözlükler yazarın mensup olduğu mezhebin tanımlarını ve bilgilerini yansıtır. Mezhebin temel kavramlarını aktarmak ve mezhep terimlerinin doğru anlaşılmasını amaçlar. Ebû Hafs Necmüddîn Ömer b. Muhammed b. Ahmed en-Nesefî es-Semerkandî'nin (öl. 537/1142) Tilbetu't-talebe fi'l-istılâhâti'l-fikhiyye alâ elfâzi kutubi'l-Hanefiyye adlı eseri, ${ }^{16}$ bu türün tipik bir örneğini oluşturmaktadır. Nesefî eserinde konu başlıklarını Hanefi fıkhına uygun olarak sıralamıştır. ${ }^{17}$ Yazar eserinde sadece terimlerin tanımını vermekle yetinmemiş, yeri geldiğinde farklı konulara da değinmiştir.

14 Zülfikar Tüccar, "Ebû Ubeyd, Kâsım b. Sellâm”, Türkiye Diyanet Vakfı İslam Ansiklopedisi (İstanbul: TDV Yayınları, 1994), 10/244-246.

15 Bu türün en tipik örneği Ebû Mansûr el-Herevî tarafından kaleme alınan ez-Zâhir fí garîbi elfâzi'ş-Şâfiî adlı eserdir.

16 Eser hakkında ilerde kısa bilgi verilecektir. Detaylı bilgi için bk. Ahmet Hamdi Furat, "Kitap Tanıtımı", İstanbul Üniversitesi İlahiyat Fakültesi Dergisi 11 (2005), 155-159.

17 Bk. Ebû Hafs Necmüddîn Ömer b. Muhammed b. Ahmed en-Nesefî es-Semerkandî, Tilbetu't-talebe fi'lıstılâhâti'l-fikhiyye alâ elfâzi kutubi'l-Hanefiyye (Misır: el-Matbaatu'l-'Âmira, 1311/1894). 
Bu türe diğer bir örnek olarak Kâsım el-Konevî'nin fıkıh terimleri alanında yazdığı Enîsü'l-fukahâ adlı eseri gösterilebilir. Bu eser Hanefi fıkhındaki kavramların detaylı tanımlarını barındırmaktadır. Başta Kur'ân, hadîs, Arap şiirleri, kelime sözlükleri ve daha öncesinde kaleme alınan benzer sözlüklerden yararlanan Enîsü'l-fukahâ adlı eserde Hanefi mezhebinin fıkıh terimlerinin yanı sıra diğer mezheplerin de bazı konulardaki görüşlerini detaylıca görmek mümkündür. ${ }^{18}$ Söz konusu bu eserlerin metot ve içerikleri hakkında ilerleyen aşamada detaylı bilgi verilecektir.

\subsubsection{2. İslami İlimlerdeki Kavramları Kapsayan Terim Sözlükleri}

Bu tür sözlükler de bilimsel dil birliğini sağlamaya yönelik değerli çalışmalardır. Belli alandaki terimleri ele alan sözlüklerden en büyük farkları, alan farkı gözetmeksizin İslami bilim dallarındaki tüm terimlerini içermeleridir. Bu tür sözlüklerin tüm kavramları tek eserde toplamış olmalarının avantajlarının yanı sıra söz konusu terimlerin hangi ekolün bakış açısını yansıttığını göstermemeleri gibi dezavantajlarının olduğunu söylemek de mümkündür. Bu tür sözlüklerin en tipik örneği Cürcânî’nin kaleme aldığı ve terim sözlükleri içerisinde İslam dünyasında derin iz bırakan önemli bir eser olan Kitâbu't-ta'rîfât adlı eserdir. Yazar eserinde alan farkı gözetmeksizin fıkıhtan felsefeye, hadisten Arap dili grameri bilim dallarına ait önemli gördüğ̈̈ yaygın kavramları ele almıştır.

\subsubsection{Dizayn Açısından Çeşitleri}

Terim sözlüklerine maddelerin dizimi ve bilgilerin sunumu açısından bakıldığında şunları söylemek mümkündür:

Genel olarak kavramların alfabetik dizilmesi tercih edilmiştir. Özellikle alan farkı gözetmeden tüm kavramları kapsayan eserlerde bunu bariz olarak görmek mümkündür. Ancak burada ince bir detay ortaya çıkmaktadır. Kimi yazarlar ele aldıkları kavramın kullanım halini baz alıp alfabetik sıralamayı ilk harften başlatmaktadır. Buna, Cürcânı̂’nin Ta'rîfât'ını örnek vermek mümkündür. Kimi yazarlar ise kavramın kök halini baz alarak yalın halindeki ilk harfin alfabetik sırasına göre kavramları sıralamıştır. Bu nedenle örneğin te'vîl maddesini ele alan Cürcânî, söz konusu kavramı alfabetik olarak be harfinden sonra te

18 Örnekler için bk. Kâsım b. Abdullah b. Mevlânâ Hayruddîn Emîr Ali er-Rûmî el-Konevî, Enîsül-fukahâ fî ta'rîfâti'l-elfâzi'l-mutedâvile beyne'l-fukahâ, thk. Ahmed b. Abdürrezzak el-Kubeysî (Cidde: Dâru'l-vefâ li'n-neşr ve't-tevzî̀', 1986) 134, 142, 199. 
harfi kapsamında değerlendirip sıralarken, ${ }^{19}$ aynı kavram Muhammed Semir Necîb el-Lebîdî

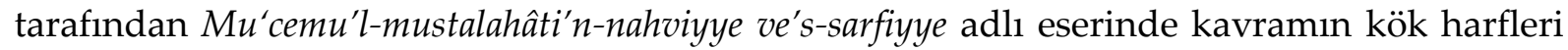
olan harfleri baz alınarak kavram hemze faslında incelenmiş ve alfabetik olarak harfinden önce sıralanmıştır. ${ }^{20}$

Alfabetik sıralamayı baz almayan özellikle de sadece fıkıh kavramlarını konu edinen Konevî'nin Enîsüll-fukahâ'sı ile Kâşânî'nin Mu'cemu'l-istilâhâti's-sûfiyye'sinde ise kavramlar söz konusu bilim dallarındaki konu dizaynına uyarlanmıştır. Bu nedenle de bu eserlerde herhangi bir kavramın geçtiği yeri bilmek ilintili olduğu bilim dalını bilmeye bağlıdır.

\subsubsection{Terim Sözlüklerinde Metot}

Söz konusu türün önde gelen örneklerine bakıldığında metot olarak şunları söylemek mümkündür:

Bazı örnekleri büyük hacimli olup kavramlar hakkında detaylı bilgi vermekte hatta konuyla uzaktan ilgili sayılabilecek tarihi, edebi dilbilimsel detayları barındıran ansiklopedi mahiyetindedirler. Örneğin Ta'rîfât adlı eserde tanımlar daha kısa ve öz şekilde verilmişken Tehânevî'nin Keşşâfu istilâhâti'il-funûn'da daha geniş tanımlama ve detaylı bilgi bulunur.

Kavramin sözlük anlamı bazen (وفي اللغة) ifadesiyle detaylandırılırken ${ }^{21}$ bazen de sözlük anlamı açıklanmadan terim anlamı ile yetinilir. Verilen örneklere bakıldığında kavramın terim ve sözlük anlamları arasında bir ilişki bulunması durumunda sözlük anlamının verildiği, herhangi bir bağlantının söz konusu olmadığı örneklerde ise sözlük anlamının verilmediği görülür. ${ }^{22}$

Kavramlar hakkında verdikleri tanımın hangi ekole ait olduğu bazen belirtilirken bazen de belirtilmemektedir. Ancak eğer söz konusu kavram farklı bilim dallarında farklı anlamda kullanılmışsa kavram kargaşası olmaması adına açıklanan kavramın hangi bilim dalı açısından tanımlandığı açıkça belirtilir. Örneğin Cürcânî, zühd (زهد) kavramını açıllarken şöyle der: ${ }^{23}$

$$
\text { الزهد في اللغة ترك الميل الى الثيء وفي اصطلاح اهل الحقيقة هو بغض الدنيا والاعر اض عنها }
$$

19 Ebü'l-Hasen Alî b. Muhammed b. Alî es-Seyyid eş-Şerîf el-Cürcânî el-Hanefî, Mu'cemu't-ta'rîfât, thk. Muhammed Sıddık el-Minşâvî (Kahire: Dâru'l-Fâdile, ts.) 46.

20 Muhammed Semir Necîb el-Lebîdî, Mu'cemu'l-mustalahâti'n-nahviyye ve's-sarfiyye (Beyrut: Müessesetü'r-Risâle / Dâru'l-Furkân, 1985), 5-6.

21 Cürcânî, et-Ta'rîfât, 52,53,58,95; Konevî, Enîsü'l-fukahâ, 67, 76, 110.

22 Farklı örnekler için bk., Mahsum Taş, Muntecebuddîn el-Hemedânî ve el-ferîd fí i'râbi'l-Kur'âni'l-mecîd adlı eserinde lügat ve sarf (Ankara: Sonçă̆, 2020), 49-56.

23 Cürcânî, et-Ta'rîfât, 99. 
Diğer bir örnek olarak da kelâm (كلام) kavramını açıklarken kullandığı şu ifadeler verilebilir:

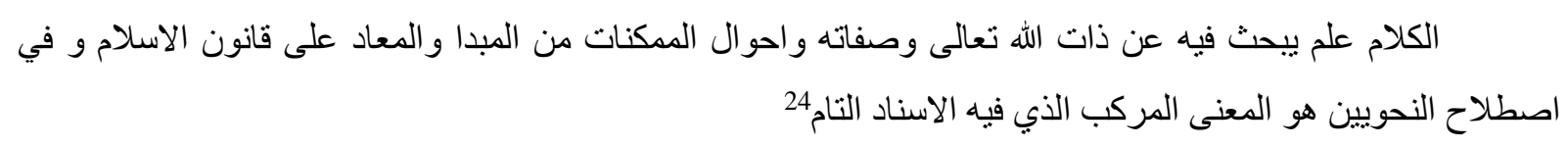

Kavramlar açıklanırken Kur'ân ve hadisler dışında beslendikleri kaynağı genelde ( و ifadesi kullanılarak meçhul bırakılıp açıklanmaz. ${ }^{25}$ Ayetler ( فيل... (فوله تعالى كما قال تعالى ) gibi ifadelerle, hadisler ise (وفي الحديث) gibi ifadeleriyle belirtilir. ${ }^{26}$

Beslendikleri kaynaklar arasında Kur'ân, hadis, Arap şiiri ve alanın önde gelen bazı temsilcileri bulunur.

Madde sıralamasında genellikle kelimenin kök harflerinden ziyade okunuşu dikkate alınarak alfabetik bir sıralama yapılmıştır. Ancak özellikle de en-Nesefî Tilbetü't-talebe adlı eserinde ve yöntem ile içerik olarak onun takipçisi olan Konevî'nin Enîsü'l-fukahâ adlı eseri gibi sadece belli bilim dalındaki kavramları ele alan sözlükler alfabetik sıralama yerine fıkıh konularına uygun şekilde kavramları ele almışlardır.

Söz konusu kavram bazlı sözlüklerin özellikle de sadece tek bilim dalındaki kavramları ele alan örneklerde bazen konu dışı meselelerin yanı sıra kavramlaşmamış bazı kelimelerin sözlük anlamlarıyla verilmesi bu eserlerin kavram sözlükleri olma iddialarına gölge düşürmektedir. Örneğin Konevî المنزل kelimesini eserinde ele alır ve sanki bir terimmiş gibi tanımlayarak şöyle der: ${ }^{27}$

$$
\text { المنزل: إسم لما يشنمل على بيوت وصحن مسقف و مطبخ ليسكنه الرجل بعياله. }
$$

\subsubsection{Terim Sözlüklerinde Kaynaklar}

Kavramları ele alan sözlüklerin beslendikleri kaynaklar çeşitlilik arz eder. Temel beslenme kaynaklarını şu başlıklar altında sıralamak mümkündür:

Kur'ân-ı Kerîm: İslamî ilimlerde kaleme alınan tüm eserlerin ana kaynağı olan Kur'ân-1 Kerîm'in kavram sözlüklerinde yoğun şekilde yer aldığı görülür. Bu da çok doğaldır. Zira İslamî ilimlerde kullanılan birçok kavram, Kur'ân’ın kullanım şekliyle kavramlaşmıştır. Bunun en büyük sebeplerinden biri de İslamî ilimlerin kahir ekseriyetinin Kur'ân ile terimleşmiş ve onunla yeni bir anlam kazanmış olmasıdır.

24 Cürcânî, et-Ta'rîfât, 155.

25 Cürcânî, et-Ta'rîfât, 59, 80, 145.

26 Cürcânî, et-Ta'rîfât, 91.

27 Konevî, Enîsü'l-fukahâ, 217. 
Hadis-i Şerîf: Kavram sözlüklerinde ikincil kaynak olarak hadislerin yer alması, vahyin tebliğcisi olan peygamberin en iyi uygulayıcısı ve açıklayıcısı olduğu gerçeğinin bir yansımasıdır. Ancak şunu söylemek gerekir ki kelimelerin kavramlaşma sürecinde hadislerin Kur'ân'a göre etkisi çok azdır. Bu nedenle de hadislerin kullanımı nispeten azdır.

Arap Edebiyatı: Arap edebiyatından kasıt şiir, darb-1 mesel ve atasözleri gibi edebi ürünlerdir. Arap edebiyatının kaynak olarak kullanımı kavramların açılanmasından ziyade genelde kelimelerin kök anlamlarının tespit ve izahında karşımıza çıkmaktadır. Arap edebiyatının özellikle kelimelerin anlamı, köken bilgisi ve dil kurallarının tespitindeki önemi açıktır.

Sözlükler: Burada sözlüklerle amaçlanan hem Halîl b. Ahmed'in Kitâbu'l-'ayn ve Cevherî'nin es-Sihâh'ı gibi kelimeleri sözlük anlamı açısından ele alan hem de Cürcânî'nin etTa'rîffât'ı gibi sadece terimleri ele alan sözlüklerdir. Sözlükler terim sözlüklerinde iki şekilde kaynak olarak kullanılmıştır. Birincisi, ele alınan terimin sözlük anlamının belirlenmesidir. Bu amaçla Cevheri'nin es-Sihâh, ile İbn Manzûr'un Lisânü'l-Arap adlı eserleri gibi kelime bazlı sözlükler kaynak olarak kullanılmıştır. İkincisi ise ele alınan kavram için verilen tanımın teyit ve tespit edilmesidir. Bu durumda da söz konusu kavramı daha önce ele almış ve aynı doğrultuda tanımlamayı yapmış önceki terim sözlükleri kullanılmıştır. Bunun da çok doğal bir durum olduğu söylenebilir. Zira her eserin, konu edindiği meselelerde daha önce alanın önde gelenleri tarafından ortaya konulmuş bilgilerden yararlanması doğal ve hatta bir nebze zorunludur.

\subsubsection{Katkı ve Amaçları}

Alan bazlı terim sözlüklerinin ilim dünyasına özellikle de bilimsel dil birliğinin oluşmasında katkıları inkâr edilemez. Zira bir kavramın tanımı hem anlaşılması hem de akılda kalıcı olabilmesi için olabildiğince kapsamlı ve kısa olması genel kabul görmüş bir durumdur. Terim sözlüklerinde bu hususlara azamî şekilde dikkat edilmiştir. Kanaatimizce başta fikıh, hadis ve tasavvuf olmak üzere İslâmî ilimlerde kaleme alınan eserlerdeki terimlerin tanımlarının benzerlik göstermesinde terim sözlüklerinin bu hususlara gösterdiği dikkatin etkisi vardır. Ayrıca mezhepsel terimlerin özellikle de müntesipleri tarafından kaleme alınan eserlerde bulunması hem mezhebin doğru anlaşılmasını sağlar hem de kavram dünyalarına aşina olma imkânını bize sunar. Ayrıca tanımlanan kavram ile ilintili olarak öne sürülen diğer tüm konu ve bilgiler bize söz konusu kavram hakkında verilen 
bilgilerin kavram için açıklanan tanım çerçevesinde geçerli olduğunu da ifade eder. Bu da lafzî ihtilaf olarak ifade edilen ihtilafın önlenmesine yardımcı olur.

Kavramları derleyen eserlerin en bariz katkısı olarak da bilimsel çalışmalarda evrensellik ve tartışılan konunun mihverinden ve odak noktasından kopmadan taraflarca müzakere edilebilmesidir. Zira zihinlerde farklı olguyu gösteren bir kavramı tartışmak, anlaşmaktan ve ortak bir sonuca varmaktan ziyade ayrışmayı ve ihtilafı beraberinde getirecektir. Zaten tarih boyunca aynı dinin müntesiplerinin birbiriyle savaşmasının temel nedeni de kanaatimizce kavramlara farklı anlam yüklemeleri ve kavramı kendi zaviyelerinden yorumlayıp karşı tarafı anlamadan hakikat gördükleri olguyu inkârla suçlamalarıdır. Nitekim hakem/tahkîm olayında ${ }^{28} \mathrm{~Hz}$. Ali taraftarlarının bir kısmının kendisinden ayrılmasındaki en büyük etken: للا حكمَ إلا لله cümlesinde geçen حكم kavramının farklı algılanması ve yorumlanmasıydı. Bu olay İslam mezhepler tarihinde olduğu kadar olayda ölenlerin durumu başta olmak üzere birçok kelamî konulardaki ekollerin ortaya çıkmasına zemin hazırlamıştır. ${ }^{29}$

Bir diğer kayda değer katkı olarak özellikle İslam bilim ve kültürüne ait kavramların güncel tutulması ve bilimsel alanda erozyona uğrayarak ortadan kaybolmasına engel olmalarıdır. Bu sözlükler sayesinde kavramlar aslî şekliyle muhafaza edilebilmekte ve ulaşılabilir olmaları nedeniyle bilim insanları tarafından kullanılması sağlanarak revaçta kalışına katkı sunmaktadırlar.

Ayrıca özellikle son dönemde kaleme alınan terim sözlükleri, klasik döneme ait kavramları yeni döneme aktarmanın yanı sıra modern dönemde bilimsel anlamda ortaya çıkan gelişmelere paralel gelişen güncel kavramların gerek Arapçaya kazandırılması gerekse de Arap dilinde o anlamı ifade edecek bir kavramın kullanılması hususunda önemli bir misyon yüklenmektedirler.

Kavramların tanımlanması ve sürekli aynı tanımın tekrar edilmesini ilmi açıdan kısır bir döngü olarak görmek ve terim sözlüklerine olumsuz bakmak kanaatimizce doğru değildir. Zira zannedildiği gibi kavramları tanımlayan eserler kendilerinden önceki eserlerin sadece nakledicisi olmamış, bilakis gördükleri eksiklikleri tamamlamış, ihtiyaç duyulan eklemeleri ve açıklamaları yapmıştır. Bu da aynı yöntemin günümüzde de geçerli olduğunu

28 Hakem olayı hakkında detaylı bilgi için bk. İsmail Yiğit - İlyas Üzüm, "Sıffîn Savaşı" Türkiye Diyanet Vakfı İslam Ansiklopedisi (İstanbul: TDV Yayınları, 2009), 37/107-108.

29 Kelam açısından hakem olayının etkileri hakkında geniş bilgi için bk. İsmail Yiğit - İlyas Üzüm, “Sıffîn Savaşı" Türkiye Diyanet Vakfı İslam Ansiklopedisi (İstanbul: TDV Yayınları, 2009), 37/107-108. 
gerekli görülmesi halinde gerekli ekleme ve detaylandırmanın bizler için de mümkün olduğunu göstermektedir.

\subsection{Terim Sözlüklerinin Önemli Örnekleri}

Sözlük yazım geleneği içerisinde önemli bir tür olan terim sözlükleri de biçim ve içerik olarak farklı örnekler arz etmektedir. Bunların önemli örneklerini de iki ana başlıkta incelemek mümkündür:

\subsubsection{Tüm Kavramları Ele Alan Sözlükler}

Kavramları ele alan sözlüklerden kasıt odak noktası ve yazım amacı olarak terimlerin izahını konu edinen eserlerdir. Bu tür eserlerin oluşum süreci aşamalı olmuştur. Nitekim Farabî'nin (öl. 339/950) İhsâu'l-'ulûm, İbn-i Sînâ'nın (öl. 428/1037) Aksâmu'l-'ulûm, Hârizmî'nin (öl. 387/997) Mefâtihu'l-‘ulûm ve Fahreddîn Râzînnin (öl. 606/1210) Hadâiku'lenvâr gibi eserler temel olarak dönemin bilim dallarıla ilgili bilgiler verirken kısmen terimleri ele almışlardır. Yani yazım amaçları ve odak noktaları terimlerin izahı değildir. Adı geçen eserlerin türün oluşum aşamasının ilk basamakları olduğunu söylemek mümkündür. Ardından hem içerik hem de biçim olarak farklı eserler ortaya konmuştur. Bu tür eserlerin tanınması adına şu örnekler verilebilir:

Seyyid Şerif Cürcânî, et-Ta'rîfât: Bilindiği kadarıyla sadece terimleri ele alan ve terim sözlügü olma hüviyetine sahip ilk eser, Cürcânî'nin et-Ta'rîfât adlı eseridir. Bu eser hem içerik hem de dizim açısından sözlük olma hüviyetine sahiptir. Anlamı "tanımlar" olan eserin ismi, tam olarak içeriğini yansıtmaktadır. Yaklaşık bin beş yüz madde barındıran eser, maddenin mevcut kullanımının ilk iki harfi esas alınarak alfabetik biçimde sıralanmıştır. Eserde ele alınan kavram bazen çeşitli bilim dalları açısından tanımlanmış ${ }^{30}$ bazen de sadece bir bilim dalına uygun şekilde tanımlanmıştır. ${ }^{31}$

Eserde yapılan tanımlarda her alanın önde gelen simalarından yararlanılmış, dil bilimlerinde Sîbeveyhi, el-Kisâî ve el-Ferrâ; fıkıhta Ebû Hanîfe, Ebû Yûsuf ve İmam Şâfiî; tasavvufta Muhyiddin İbnü'l-Arabî, Ebû Tâlib el-Mekkî ve Abdülkerîm el-Kuşeyrî gibi bilginlerden yararlanılmıştır. Faydalanan eser ve kişilere bakıldığında yazarın eserini

30 Örnek için bk. Cürcânî, et-Ta'rîfât, 62; Tevhit maddesi; Cins maddesi, 70; hal maddesi, 72.

31 Örnekleri için bk. Cürcânî, et-Ta'rîfât, 45 Tabiun maddesi; 55 Tazir maddesi; 62 tavdih maddesi. 
mensup olduğu herhangi bir mezhep veya ekolün düşünce kalıbına hapsetmeyip, dönemin ilmi otoritelerinden yararlanarak eserini kolektif bir bilgi hazinesi haline getirdiği görülür. ${ }^{32}$

$\mathrm{Bu}$ eser günümüze kadar önemini korumuş, alanda yetkin olarak bir boşluğu doldurmuş ve kendisinden sonra gelen başta Ebü'l-Bekâ'nın el-Külliyyât'ı, Tehânevî'nin Keşşấü ıștılâhâti'l-fünûn ve'l- 'ulûm'u ve Riza Tevfik'in Mufassal Kâmûs-ı Felsefe'si gibi eserlerin gerek içerik gerekse de biçim olarak öncüsü olmuştur.

Muhammed Abdürrauf el-Münâvî, et-Tevkîif 'alâ mühimmâti't-te'ârîf: İslamî ilimlerin hemen hemen tüm dallarında eser veren çok yönlü ansiklopedik alimlerden olan elMünâvî (öl. 1031/1622), yaklaşık üç bin madde ihata eden eserini büyük ölçüde Cürcânî́nin et-Ta'rîfât'inı baz alarak oluşturmuş, ${ }^{33}$ ayrıca ek olarak et-Ta'rîfât'ta bulunmayan bir çok kavramı da ekleyerek daha geniş bir eser ortaya koymuştur. ${ }^{34}$ Kaynak olarak ayet, hadis, dil ve alanın önde gelen şahsiyetlerin görüşlerini kullanmıştır. Yöntem olarak da alfabetik sıralamayı seçmiştir. ${ }^{35}$

\section{Muhammed A`lâ b. Alî b. Muhammed Hâmid et-Tehânevî el-Fârûk, Keşşafu} istilâhâti'i-funûni ve'l-'ulûm: Bu eser söz konusu türün en geniş ve en güncelidir. Eserine bilim dallarına ait geniş malumat içeren bir girişle başlayan et-Tehânevî, (öl. 1158/1745'ten sonra) eserini üç ana bölümde kurgulamış: birinci bölümde filoloji, ikinci bölümde fıkıh ve tefsir gibi dini bilimler, üçüncü bölümde ise felsefe, mantık, matematik gibi akli bilimleri ele alarak söz konusu alanların terimleri hakkında geniş bilgiler vermiştir. İçerisinde Farsça terimleri barındıran bir kısım bulunmakta ve bu terimler tamamen Farsça açıklanmıştır. Yazar başta Seyyid Şerif Cürcânî'nin et-Ta'rîfât'ı olmak üzere birçok kaynaktan yaralanmıştır.

Tehânevî'nin eserinde uyguladığı yöntem hakkında şunları söylemek mümkündür: Kavramın öncelikle sözlük olarak açıklaması yapılmış, ardından da ait olduğu bilim veya bilimlerdeki terim anlamı izah edilmiştir. Bu açılamaları genelde kısa tutmakla beraber gerekli olduğuna inandığı bilgi ve konuları detaylıca açıklamaktan da geri kalmamıştır. Konuların açıklanmasında kaynak olarak önde gelen eserlerden yararlandığı gibi alanın önde gelen eserleri ve fikir öncüleri hakkında da bilgi vermiştir. Kavramların diziminde ise

\footnotetext{
32 Eser hakkında detaylı bilgi için bk. Sadreddin Gümüş, "et-Ta'rîfât", Türkiye Diyanet Vakfı İslam Ansiklopedisi (İstanbul: TDV Yayınları, 2011), 40/29-30.

33 Örnek olarak bk. Cürcânî, et-Ta'rîfât, 48; Muhammed Abdürrauf el-Münâvî, et-Tevkîf 'alâ mühimmâti't-te 'ârîf, thk. Abdülhamid Salih Hamdan, (Kahire: Âlemu'l-Kutub, 1990), 91.

34 Geniş bilgi için bk. M. Yaşar Kandemir, "el-Münavî”, Türkiye Diyanet Vakfı İslam Ansiklopedisi (İstanbul: TDV Yayınları, 2006), 31/575.

35 Bk. el-Münâvî, et-Tevkîf.
} 
alfabetik sıralamayı benimsemiş, kavramın ilk harfini baz alarak aynı kökten türeyen maddeleri de ardından gelecek şekilde tasarlamıştır. ${ }^{36}$

\subsubsection{Belli Bir Bilim Dalının Terimlerini Ele Alan Sözlükler}

Kavram sözlükleri bazen belli bir bilim dalına tahsis edilir. Tüm bilim dallarında aynı sayıda eser kaleme alınmamıştır. Bazı alanlar diğer alanlara nispeten daha çok rağbet görmüştür. Bunun nedenleri arasında bilim dallarının oluşum süreçlerinin yanı sıra doğaları gereği bazılarının diğerlerine nazaran daha çok terim barındırması gösterilebilir.

\subsubsection{Fikıh İlmi}

Fıkıh ilminin terimlerini alan eserler terim sözlüklerinin en yaygın telif edildiği alandır. Bunların başlıca örneklerini içerik ve yöntem açısından şöyle sıralamak mümkündür:

\section{Ebû Hafs Ömer b. Muhammed b. Ahmed b. Lokman en-Nesefî, Tilbetu't-talebe} fi'l-istilâhâti'l-fıkhiyye: Bu eser fıkıh terimleri alanında kaleme alınmış ilk eser olarak kabul edilir. Yazar eseri kaleme alma nedenini şöyle izah etmektedir:

İlim ehlinden bir grup, ilim ve edebiyat öğrenmekte henüz fazla ilerlememiş, mezhep İmamlarımızın kitaplarında zikredilen Arapça lafızları ve nükteleri anlama mahareti kazanamamış gençlere zor gelen ifadeleri açılamamı benden istedi. Onlara yardımcı olmak ve kendilerini başka kaynaklara müracaat külfetinden kurtarmak için bu eseri yazdım. ${ }^{37}$

Tilbetu't-talebe, konuların tertibi açısından Hanefi fıkıh kitaplarının genel üslûbuyla paralellik arz eder. Eserde Hanefi fıkhında işlenen bölüm başlıkları ve fıkıh kitaplarında bu başlıklar altında yer alan meselelerde geçen ıstılahlar, kelime ve terkipler İncelenmiştir. Mesela, rehn bölümünde önce rehn kelimesinin anlamı üzerinde durulmuş, daha sonra bununla ilgili Râhin, îrhân, fekku'r-rehn, iftikâk gibi Hanefi kitaplarında geçen çeşitli tabirler üzerinde durulmuştur. Bu istılahlar öncelikle dil açışından incelenmekte ve bazen de ıstılahın aslen Arapça mı yoksa diğer bir dilden mi Arapçaya girmiş olduğu hakkında bilgi verilmektedir. Bu açıklamaları, söz konusu ıstılahların fıkıh literatüründeki anlamları takip eder. Istılahî anlam açıklanırken genellikle Kur'ân'dan ve Hadis'ten deliller getirilir. Bu ıstılahların izahı için bazen şiirlere de başvurulur. Nesefî, ıstılahların açıklanmasında fıkıh

\footnotetext{
${ }^{36}$ Bk. Muhammed A’lâ b. Alî b. Muhammed Hâmid et-Tehânevî el-Fârûk, Keşşâfu istilâhâti'i-funûni ve'l-'ulûm, thk. Ali Dahrûc (Lübnan: Mektebetu Lübnân Nâşirûn, 1996).

37 en-Nesefî, Tilbetü't-talebe, 2.
} 
kitaplarının yanı sıra bazı dil ve edebiyatla ilgili eserlerden de istifade etmiştir. Bu kitaplardan bazılarını müellifleriyle beraber zikretmiştir. Arapça kaynakların yanı sıra Farsça eserlerden de yararlanmıştır.

Ebû Mansûr Muhammed b. Ahmed el-Ezheri el-Herevî, ez-Zâhir fî̀ garîbi elfâzi'şŞafîi: Tam olarak terim sözlükleri olmasa da bu türden sayılabilecek öncül çalışmalardan biri de Ebû Mansûr Muhammed b. Ahmed el-Ezherî el-Herevî (öl.370/980) tarafından kaleme alınan ez-Zâhir fî Garîbi Elfâzi'ş-Şafiî ismiyle bilinen eserdir. Yazar eserinde İmam Şafii'nin talebelerinden İsmail b. Yahya el- Müzenî’nin Muhtasaru'l Muzani kitabını esas almış ve bu kitaptan aldığı kelimeleri mezhepsel olarak fıkıh zaviyesinden açıklamıştır. Kitapta ele alınan konular şafii mezhebinin sistematiğinde ele alınmıştır. Ancak şunu da belirtmeliyiz ki bu eser tam bir fıkıh terimleri sözlüğü değildir. Belki de fıkıh eserlerinden fıkıh terimleri eserlerine dönüşüm sürecinin köprü örneği konumunda görülebilir. ${ }^{38}$

Kâsım b. Abdullah el-Konevî, Enîsü'l-fukahâ fî̀ ta'rîfâti'l-elfâzi'l-mutedâvile beyne'l-fukahâ: Enîsü'l-fukahâ, Hanefi mezhebi ekseninde kaleme alınmış önemli bir fikıh terimleri sözlüğüdür. Yazar eserini, Hanefi mezhebi geleneği fıkıh kitaplarına uygun olarak konu bazlı şekilde dizayn etmiştir.

Konevî̀nin kaleme aldığı bu eserin ismi hakkında farklı bazı kayıtlar bulunsa da gerek yazarın mukaddimedeki tescili gerekse de bibliyografya yazarları tarafından tescil edilen kayıtlar, eserin orijinal isminin 'Enîsü'l-fukahâ fî̀ ta'rîfâti'l-elfâzi'l-mütedâvile beyne'lfukahâa' olduğunu göstermektedir. Eser, ana muhteva olarak fıkıh terimlerini konu edinir. Ancak terimleri açıklarken konuyu tüm boyutlarıyla irdeleyerek ana konuyla ilintili fıkıh, iştikâk, mezhepler arası mukayese ve konuların tertibine dair bilgileri de aktarır.

\subsubsection{Tasavvuf}

Temel İslam bilimleri içerisinde yer alan tasavvuf, birçok ilim dalı gibi erken dönemde diğer temel İslam bilimleri ile iç içe iken zamanla belli kural ve kuramı olan özgün bir bilim dalı haline gelmiştir. Barındırdığı mistik yapısı nedeniyle en çok girift ve izaha muhtaç kavramlara sahip olan bilim dalı olduğunu söylemek mümkündür. Bu nedenle de fıkıhtan sonra terim sözlüklerinin en çok telif edildiği bilim dalı olarak öne çıkmaktadır. Bu türün en yaygın olan eserlerini şöyle örneklendirebiliriz:

\footnotetext{
38 Bk. Ebû Mansûr Muhammed b. Ahmed el-Ezheri el-Herevî, ez-Zâhir fî̀ Garîbi Elfâzi'ş-Şafî̀, thk. Mis'ad Abdülhamid es-Sa'denî (Kahire: Dâru't-Talâi', ts.)
} 
Kemâlüddîn Abdürrezzâk b. Ebi'l-Ganâim Muhammed el-Kâşânî (öl. 736/1335), Mu'cemu istilâhâti's-sûfiyye: Yaklaşık beş yüz tasavvuf terimini alfabetik olarak ele alan Kâşânî, özellikle Muhyiddîn İbnü'l-Arabî'nin (öl. 638/1240) kullandığ1 tasavvuf terimlerinin anlaşılmasının zor olması ve bu terimlerin birçok kişi tarafından anlaşılmaması nedeniyle böyle bir eser yazma ihtiyacı hissettiğini söyler. ${ }^{39}$ Alanda eser yazan öncülerden olması hasebiyle gerek tasavvuf gerekse de tüm alanların terimlerini ele alan eserlerde bariz etkide bulunmuştur. ${ }^{40}$ Yöntem olarak alfabetik dizaynı seçmiş; terimin mevcut kullanım şekliyle ilk iki harfini esas almıştır.

Eymen Hamdî, Kâmûsu'l-mustalahâti'-sûfiyye: Modern dönemin tasavvuf terimleri sözlük örneklerinden olan bu eser yaklaşık iki yüz maddeyi alfabetik sıraya göre ele almıştır. $\mathrm{Bu}$ eserin klasik dönem eserlerden en özgün yanı tasavvuf terimlerinin izahında söz konusu terimin kullanımına dair tasavvufçulardan da alıntı yapmasıdır. ${ }^{41}$

\subsubsection{Hadis}

Hadis alanındaki terimleri ele alan sözlükler de kavram bazlı sözlüklerin önde gelen bir türüdür. Bu konuda da çeşitli boyut ve yöntemde eserler kaleme alınmıştır.

Ebû Abdillâh Muhammed b. Sâlih b. Muhammed b. Süleymân el-Useymîn etTemîmî (öl. 2001) Mustalahu'l-hadîs: Arabistan'ın Necd bölgesinde 1929 tarihinde doğan ve el-Useymîn adıyla meşhur olan yazar, eserinde hadis literatüründeki kavramları derlemiştir. Yaklaşık iki yüz kavramı ele alan yazar sadece kavramları açıklamakla yetinmemiş; hadis ilminin oluşumu, önemi ve temel kaynakları hakkında da bilgiler vermiştir. Metot olarak da hadis ilminin konu sıralamasına uygun şekilde kavramları sıralama metodunu uygulamıştır.

\subsubsection{Gramer}

Bilindiği üzere Arap dili grameri kuralları erken dönemde, özellikle de fetihlerin artması ve İslam dinine yeni milletlerin de dahil olması neticesinde Arap dilinde artan lahn/yanlış/hata tehlikesine karşı geliştirilmiş ve kısa zamanda sistematik bir hale getirilmiştir. Zamanla sistematize edilmiş bu kuralların derlendiği sözlük türü eserler de ortaya konmuştur. $\mathrm{Bu}$ eserler fıkıh, hadis ve tasavvuf bilimleri gibi erken dönemde

39 Kemâlüddîn Abdürrezzâk b. Ebi'l-Ganâim Muhammed el-Kâşânî, Mu'cemu istilâhâti's-sûfiyye, thk. Abdülali Şâhin (Kahire: Dâru'l-Menâr, 1992), 46.

40 Örnek için bk. Cürcânî, et-Ta'rîfât, 14, Ahad maddesi, 84, hâtir maddesi, vb.

${ }^{41}$ Örnekler için bk. Eymen Hamdî, Kâmûsu'l-mustalahâti's-sûfiyye (Kahire: Dâru Kubâ', 2000), 63,76. 
başlamamış ve ortaya konan eserler de nispeten farklılık arz etmiştir. Zira gramer bir kavram bilimi olmaktan ziyade kurallar bilimidir. Bu alanda ilk nüvenin İbn Hişâm (öl. 761/1360) tarafından Muğni'l-lebîb 'an kutubi'l-e'ârib adlı eserle ortaya koyulduğunu söylemek mümkündür. İlerleyen süreçte İbn Hişam'dan esinlenerek gramer alanındaki terimleri ele alan değerli eserler ortaya konmuştur. Ancak bu eserlerin hem sistematik hem de içerik olarak özgün ve müstakil hale gelmesi maalesef diğer bilim dalları kadar erken dönemde olmamış veya elimize örnekleri ulaşamamıştır. Bu alanda alfabetik olarak dizayn edilmiş ve sözlük tanımına uygun hale gelmiş örnekleri modern dönemde olmuştur. Arap dili grameri alanında ortaya konan terim sözlüklerine şu örnekleri vermek mümkündür:

İbn Hişam, Muğni'l-lebîb 'an kutubi'l-e'ârib: İbn Hişâm'ın en önemli eseri olarak gösterilebilen Muğni'l-lebîb, özellikle de takip edilen yöntem açısından zamanın diğer gramer eserlerinden farklılık arz etmektedir. Ayrıca içerik olarak da özgün bir konuma sahiptir. Zira içerik olarak sadece kuralları barındırmamakta, edatlar ve bazı kelimelerin kullanıldığı farklı anlamların yanı sıra cümle/şibh-i cümle ile ilgili kural, yorum ve tahliller de barındırmaktadır. Müfretler ve cümleler olmak üzere iki ana bölüm ve sekiz alt başlıkta kurgulanan eser² özellikle de müfretler konusunda bazı edatların ve kelimelerin kullanıldığı farklı anlamları barındırması açısından sözlük hüviyetini kazanmaktadır. Bu açıdan bakıldığında gramer ilmindeki terim sözlükleri için öncül örnek olarak gösterilmesi mümkündür.

Zeynelabidîn et-Tûnusî, el-Mu'cem fi'n-nahvi ve's-sarf: Eserinde yaklaşık üç yüz madde inceleyen yazar, kavramların yanı sıra Arap dilindeki edat ve önemli gördüğü kelimeleri işlemiştir. Araştırmacılara kolaylık olsun diye maddeleri modern tarzda alfabetik olarak ele aldığını belirtmektedir. ${ }^{43}$

Muhammed Muhammed Hasan Şurrâb, Mu'cemu'ş-şevâridi'n-nahviyye ve'lfevâidi'l-lugaviyye: Yazar eserinde gramer kavramlarının yanı sıra edatlar ve kavramlar hakkında bilinmesi gerekli bilgileri kısa ve örneklendirerek vermiştir. Ayrıca cümle içerisinde diğer kelimelere etki eden avâmili ele almış ayrıca anlamlarını ve çeşitlerini de aktarmıştır. Arapçada emsalinden farklı olarak kullanılan darb-ı meseller, terkip ve

42 Detaylı bilgi için bk. Mehmet Reşit Özbalıkçı, "Muğni'l-lebîb”, Türkiye Diyanet Vakfı İslam Ansiklopedisi (İstanbul: TDV Yayınları, 2005), 30/384-386.

43 Zeynelabidîn et-Tûnusî, el-Mu'cem fi'n-nahvi ve's-sarf, nşr. Ali Rıda et-Tûnusî (Dımaşk: y.y., 1405/1985). 
cümleleri de irdelemiştir. Son olarak da yaygın kurallara aykırı kullanımları da belirtmiştir. Yazar eserini alfabetik olarak kaleme almıştır. ${ }^{44}$

Muhammed Semir Necîb el-Lebîdî, Mu'cemu'l-mustalahâti'n-nahviyye ve'ssarfiyye: Eserinde yaklaşık bin madde ele alan yazar, alanda kaleme alınmış birçok eserin bulunmasına rağmen böyle bir çalışmayı gerekli görmesini şöyle açılamaktadır:

\begin{abstract}
Alanda telif edilmiş modern eserlerin yaygın olarak edatlara ve kelimelerin anlamını açıklamaya yöneldiği, kavramlara gerekli hassasiyeti göstermediklerini gördüm. Bu eserlerden bazılarında ise tahlili zor olan cümlelere yer verilmiştir. Doğrusu söz konusu yazarlar ortaya koydukları eserleriyle alana önemli katkı sunmuş olmakta ve teşekkürü hak etmektedirler. Ancak daha çok kavramlara odaklanmış bir eserin boşluğuna inanmaktaydım. Bu inancım nedeniyle alfabetik olarak dizayn ettiğim ve sadece kavramlara odaklandığım bu eseri, öğrencilerin ve araştırmacıların bilgiye erişimini kolaylaştırmak amacıyla kaleme almayı gerekli gördüm. ${ }^{45}$
\end{abstract}

Yazar, kavramın kök harflerini baz alarak eserini alfabetik sıralamaya tabi tutmuştur. Diğer bir deyişle kavramın mevcut kullanım şeklini değil de kök harflerindeki sıralamayı önemsemiş ve köken harfini baz alarak alfabetik olarak sıralamıştır. Örneğin ele aldığ1 te'vîl/تأويلkavramını, kökeni olan أول harflerini dikkate alarak hemze harfinde ele almıştır. Bu da özellikle modern dönemde yazılmış birçok alan sözlüklerinin yönteminden farklı bir uygulamadir.

\title{
Sonuç
}

Arap edebiyatında bilimsel dil birliğini sağlamaya yönelik çabanın bir ürünü olarak kavram/alan/terim sözlükleri ve temel özelliklerini ele aldığımız bu çalışmada varılan sonuçları ve elde edilen yeni verileri başlıklar halinde şöyle sıralamak mümkündür:

$\checkmark$ İslam dünyasında kelimelerin sözlük anlamlarına yönelik çalışmalar yapıldı̆̆ gibi terimlerin tanımsal birliğine yönelik önemli çalışmalar yapılmıştır.

$\checkmark$ Günümüzde dahi bu tür eserlerin hem Türkçe hem de Arapça kaleme alınmaya devam edilmesi terim sözlüklerinin önemini ispatlar mahiyettedir.

$\checkmark$ Bu çalışmalar sayesinde sonraki süreçlerde kavramların tanımında gözle görülür birlik sağlanmış ve İslam kültürüne ait kavramların bilim dünyasında güncel tutulmasına önemli katkı sunulmuştur. Zira bu sözlükler sayesinde kavramlar aslî/orijinal Arapça

44 Muhammed Muhammed Hasan Şurrâb, Mu'cemu'ş-şevâridi'n-nahviyye ve'l-fevâidi'l-lugaviyye (Beyrut: Dâru'lMe'mûn li't-Turâs, 1411/1990).

45 el-Lebîdî, $M u^{\prime}$ cemu'l-mustalahâti'n-nahviyye ve's-sarfiyye, 5-6.

46 el-Lebîdî, Mu'cemu'l-mustalahâti'n-nahviyye ve's-sarfiyye, 15. 
şekliyle muhafaza edilebilmekte ve bilim insanları tarafından aynı literatürün kullanılması sağlanabilmektedir. Özellikle modern dönemde kaleme alınan terim sözlükleri, küresel çapta ortaya çıkan yeni bilimsel kavramların Arap diline uyarlanması veya onu ifade edecek bir kavramın türetilmesi konusunda önemli bir misyon yüklenmektedirler.

$\checkmark$ Terimlerin ele alındığı çalışmalar, metot ve yöntem açısından benzerlikleri nedeniyle sözlük çalışmaları kapsamında değerlendirilebilir.

$\checkmark$ Terim sözlüklerini diğer sözlüklerden ayıran en önemli özellik kaynaklarının farklılığıdır. Zira kelime bazlı sözlükler çoğunlukla Arap dili ve eski şiirleri kaynak olarak kullanırken terim sözlükleri daha çok Kur'ân, hadis ve mesleki alan eserlerini kullanır.

$\checkmark$ Terim sözlükleri yaygın olarak ele aldıkları kavramların diziminde kavramın mevcut kullanım şeklini baz alırlar. Kelimenin kökeni esas alınarak yapılan dizim sistemi bunlarda nadir kullanılmaktadır. Bunun temel sebebi de kavramın kök halinden ziyade mevcut şekliyle kavramsallaşmış olmasıdır.

$\checkmark$ Terim sözlükleri muhteva açısından çeşitlilik arz eder. Nitekim Cürcânî'nin etTa'rîfât adlı eserinde olduğu gibi kimi terim sözlükleri alan farkı gözetmeksizin İslamî ilimlerdeki tüm önemli kavramları konu edinirken, el-Konevî'nin Enîsü'l-fukahâ adlı eserinde olduğu gibi kimi eserlerde de sadece bir alanın kavramları belli bir ekolün penceresinden ele alınmıştır.

$\checkmark$ Terim sözlükleri muhteva açısından olduğu gibi metot açısından da çeşitlilik göstermektedir. Belli konulardaki kavramları kapsayan terim sözlüklerinde genel olarak söz konusu alanın etkileri görülürken alan farkı gözetmeden tüm kavramları ele alan terim sözlüklerinde ise alfabetik sıralamanın tercih edildiği gözlemlenmiştir.

$\checkmark$ Terim sözlüklerinde kaynak olarak Kur'ân, hadis, kavramın ilgili olduğu alandaki önde gelen eserler, terim ve kelime bazlı sözlüklerin yanı sıra Arap dili ve şiiri de kullanılmıştır.

$\checkmark$ Tüm bilim dallarındaki terim sözlükleri doğal olarak söz konusu bilimin teşekkül sürecini tamamlanmasından sonra ortaya çıtı̆̆ını söylemek mümkündür. Veya en azından teşekkül sonrası ortaya çıkan eserlerin daha isabetli kavram tanımı vereceğini iddia etmek yanlış olmayacaktır.

$\checkmark$ Klasik dönem terim sözlükleri ile modern dönem terim sözlükleri amaç ve içerik olarak çok büyük bir benzerlik arz etse de modern dönem terim sözlükleri ortaya çıan yeni 
kavramların eklenmesiyle özellikle içerik açısından daha çok zenginleşmiş, hacimli hale gelmiş ve geçmişe dair birikimden yararlanmak suretiyle sistematiği daha çok oturmuştur.

$\checkmark$ Son olarak kavramları ele alan eserlerin ana hedeflerinden ilki kavram birliği sağlamak, özlü bilgiye ulaşmak olsa da ikinci ana hedefin ise herhangi bir kavram ile ilgili bilgi edinmeyi kolaylaştırmak ve bilgiye erişimi hızlı ve kolaylaştırmak olduğunu söylemek mümkündür. 


\section{Kaynakça}

Afif, Abdurrahman. Min kadâye'l-mu'cemâti'l-'Arabiyyeti'l-mu'âsıra. Tunus: Daru'l-Garbi'lİslamî, 1986.

Aksan, Doğan. Her Yönüyle Dil. Ankara: TDK Yayınları, 1995.

Alpak, Mehmet Nuri. Arap Dilinde Sözlük Çalışmaları ve Nazım Efendi'nin 'Tercümanu'l-lügat' Adlı Eserinin İncelenmesi. Van: Yüzüncü Yıl Üniversitesi, Sosyal Bilimler Enstitüsü, Yüksek Lisans Tezi, 2006.

Attâr, Ahmed Abdülğafûr. Mukaddimetü's-sihâh. Misır: y.y., 1956.

Cürcânî, Ebü'l-Hasen Alî b. Muhammed b. Alî es-Seyyid eş-Şerîf el-Hanefî. Mu'cemu'tta'rîfât. thk. Muhammed Siddık el-Minşâvî. Kahire: Dâru'l-Fâdile, ts.

Çelikkol, Suat. Sözlük Çalışmalarında Dilbilimsel Açıdan Yaklaşım ve Dr. Abdulvahid Kerem'in 'Mucemu'l-Mustalahati'l-Kânuniyye' Adlı Eseri ve Türkçeye Tercümesi. Sivas: Cumhuriyet Üniversitesi, Sosyal Bilimler Enstitüsü, Yüksek Lisans Tezi, 1998.

Çöğenli, M. Sadi - Demirayak, Kenan. Arap Edebiyatında Kaynaklar. Erzurum: Fen-Edebiyat Fakültesi Yayınları, 1994.

Emin, Ahmed. Duha'l-İslam. Kahire: y.y., 1964.

Eymen, Hamdî. Kâmûsu'l-mustalahâti's-sûfiyye. Kahire: Dâru Kuba', 2000.

Furat, Ahmet Hamdi. "Kitap Tanıtımı". İstanbul Üniversitesi İlahiyat Fakültesi Dergisi 11 (2005), 155-159.

Gümüş, Sadreddin. "et-Ta'rîfât". Türkiye Diyanet Vakfı İslam Ansiklopedisi. 40/29-30. İstanbul: TDV Yayınları, 2011.

Herevî, Ebû Mansûr Muhammed b. Ahmed el-Ezherî. ez-Zâhir fî Garîbi Elfâzi'ş-Şafiî. thk. Mis'ad Abdülhamid es-Sa'denî. Kahire: Dâru't-Talâi', ts.

Kandemir, M. Yaşar. "el-Münavî”. Türkiye Diyanet Vakfı İslam Ansiklopedisi. 31/575. İstanbul: TDV Yayınları, 2006.

Kâşânî, Kemâlüddîn Abdürrezzâk b. Ebi'l-Ganâim Muhammed. Mu'cemu istilâhâti's-sûfiyye. thk. Abdülali Şâhin. Kahire: Dâru'l-Menâr, 1992.

Konevî, Kâsım b. Abdullah b. Mevlânâ Hayruddîn Emîr Ali er-Rûmî. Enîsü'l-fukahâ fi ta'rîfâti'l-elfâzi'l-mutedâvile beyne'l-fukahâ. thk. Ahmed b. Abdürrezzak el-Kubeysî. Cidde: Dâru'l-Vefâ li'n-Neşr ve't-Tevzî', 1986.

Küçükkalay, Hüseyin. Kur'ân Dili Arapça. Konya: y.y., 1969.

Lebîdî, Muhammed Semir Necîb. Mu'cemu'l-mustalahâti'n-nahviyye ve's-sarfiyye. Beyrut: Müessesetü'r-Risâle/Dâru'l-Furkân, 1985.

Muhtar, Cemal. "İslâm'da Sözlük Çalışmaları II". Marmara Üniversitesi İlahiyat Fakültesi Dergisi 3 (1985), 353-354.

Münâvî, Muhammed Abdürrauf. et-Tevkîf 'alâ mühimmâti't-te ârîf. thk. Abdülhamid Salih Hamdan. Kahire: Âlemu'l-Kutub, 1990.

Nassâr, Hüseyin. el-Mu'cemu'l-Arabî, neş'etuhu ve tatavouruhu. Mısır: y.y., 1988.

Nesefî, Ebû Hafs Necmüddîn Ömer b. Muhammed b. Ahmed es-Semerkandî. Tilbetu't-talebe fi'l-ıstılâhâti'l-fikhiyye alâ elfâzi kutubi'l-Hanefiyye. Misır: el-Matbaatu'l-'Âmira, 1311/1894.

Reşit Özbalıkçı, Mehmet. “Muğni'l-lebîb”. Türkiye Diyanet Vakfı İslam Ansiklopedisi. 30/384386. İstanbul: TDV Yayınları 2005.

Sezgin, Fuat. GAS (Geschichte des Arabischen Schrittums). 9 Cilt. Leiden: y.y., 1967-1984.

Şurrâb, Muhammed Hasan. Mu'cemu'ş-şevâridi'n-nahviyye ve'l-fevâidi'l-lugaviyye. Beyrut: Dâru'l-Me'mûn li't-Turâs, 1411/1990. 
Taş, Mahsum. Muntecebuddîn el-Hemedânî ve el-ferîd fî̀ i'râbi'l-Kur'âni'l-mecîd adlı eserinde lügat ve sarf. Ankara: Sonçağ, y.y., 2020.

Tehânevî, Muhammed A'lâ b. Alî b. Muhammed Hâmid el-Fârûk. Keşşâfu istilâhâti'i-funûni ve'l-'ulûm. thk. Ali Dahrûc. Lübnan: Mektebetu Lübnân Nâşirûn, 1996.

Topuzoğlu, Tevfik Rüştü. "Halîl b. Ahmed". Türkiye Diyanet Vakfı İslam Ansiklopedisi. 15/309312. İstanbul: TDV Yayınları, 1997.

Tüccar, Zülfikar. "Ebû Ubeyd, Kâsım b. Sellâm”. Türkiye Diyanet Vakfi İslam Ansiklopedisi. 10/244-246. İstanbul: TDV Yayınları, 1994.

Vardar, Berke. Açıklamalı Dilbilim Terimleri Sözlü̈̆̈̈̈. İstanbul: y.y., 1998.

Yakub, Imîl Bedî. el-Me'âcimu'l-lugaviyyetü'l-Arabiyye. Beyrut: Dâru'l-İlm li'l-Melâyîn, 1985.

Yavuz, Mehmet. "Mu'arreb Kelimelere Dair Yazılan Eserler Sözlükler". Nüsha (Şarkiyat Araştırmalarl) Dergisi 1/2 (2001), 112-119.

Yiğit, İsmail - Üzüm, İlyas. "Sıffîn Savaşı". Türkiye Diyanet Vakfı İslam Ansiklopedisi. 37/107108. İstanbul: TDV Yayınları, 2009.

Zaza, Hasan. Kelâmu'l-'Arab min kadâya'l-luğati'l-'Arabiyye. Beyrut: y.y., 1990.

Zeynelabidîn et-Tûnusî. el-Mu'cem fi'n-nahvi ve's-sarf. nşr. Ali Rıda et-Tûnusî. 4. Basım, Dımaşk: y.y., 1405/1985. 